\title{
Sustainability as an Identity Factor of Tourist Destinations at Websites: Does the Consumer Care?
}

\author{
Francisco Vicente Sales Melo ${ }^{\dagger}$ \\ Pernambuco Federal University \\ Salomão Alencar de Farias ${ }^{\Omega}$ \\ Pernambuco Federal University
}

\begin{abstract}
When choosing a vacation destination, consumers consider various factors, such as culture, natural attractions, history and points of interest, among others. In this article we analyze whether the question of sustainability is a determining factor in the choice of tourist destinations. Therefore, the article investigates the relationship of the identity of tourist destinations, as presented at their official websites, according to sustainability characteristics, the evaluation of the destination and the intention of consumers to visit it. For this purpose, we conducted a quasi-experiment with official tourism websites of two countries, Brazil and Holland. The results reveal that the respondents did not tend to have positive attitudes regarding destinations that emphasize questions of sustainability in their promotion via websites. Furthermore, these elements do not appear to contribute to formation of a positive image and to increase the intention of visiting the destination.
\end{abstract}

Keywords: Sustainability. Identity. Tourist destinations. Websites.

*The authors would like to thank the following agencies for the support on the development of the research that resulted in this paper: CAPES, CNPQ e FACEPE.

*Author for correspondence:

$\uparrow$. PhD student in the Graduate Program in Administration of

Pernambuco Federal University(UFPE).

Institution: Assistant professor in the Administrative Sciences

Department of Pernambuco Federal University.

Address Avenida Professor Moraes Rego, Recife -

Pernambuco - Brazil - E-mail: vicsmelo@ gmail.com

Telephone: (81) 2126-7174
$\Omega$ Postdoctora 1 fellow at Georgia State University and CPPC North Carolina and PhD in Administration from the University of São Paulo

Institution: Professor in the Administrative Sciences Department of Pernambuco Federal University

Address Avenida Professor Moraes Rego, Recife - Pernambuco - Brazil

E-mail: saf@ufpe.br.

Telephone: (81) 2126-7174 


\section{INTRODUÇÃO}

$\mathrm{n}$ choosing a vacation destination, consumers consider various factors, such as culture, natural attractions, history and points of interest, among others. This article examines whether the question of sustainability also is a factor that determines the choice of tourist destinations, i.e., whether a tourist destination, in positioning itself as sustainable, would improve its image and attract more tourists.

This study is relevant because the longstanding theoretical discussion about the environment (HERBERGER, 1975) and sustainability shows that these questions contribute to the awareness of individuals and more sustainable behavior by societies. As a consequence, consumers are influenced by these questions in their buying behavior (TUCKER, 1980; MARTIN; SIMINTIRAS, 1995; LEE; HOLDEN, 1999; CHEN; CHAI, 2010; OKADA; MAIS, 2010; HANSS; BÖHN, 2012). Therefore, with respect to the evaluation of a vacation destination, it is probable that individuals will tend to have more positive attitudes and favorable intentions when a destination adopts sustainable practices.

Sustainability can be understood as the equitable distribution of natural resources between generations, centered on social equality, cultural diversity, economic efficiency and protection and preservation of the environment (CIEGIS; CIEGIS; JASINSKAS, 2005). With heightened public awareness of environmental issues, sustainability has become an institutional motivational and mobilization factor (HUNTER, 2002; CIEGIS; CIEGIS; JASINSKAS, 2005).

The image of a destination consists of the sum of the beliefs, ideas and impressions of tourists about the place (CROMPTON, 1979; KOTLER et al., 2006). In turn, a destination's identity is composed of the characteristics that set it apart as a possible tourist destination. The image of a product or service is based on the elements that support the system of identity of an organization, which is the starting point to construct a positive concept (ALBERT; WHETTEN, 1985; DHALLA, 2007).

The competition between destinations means the identity of a place must be understood from a more integrated perspective (PIMENTEL; PINHO; VIEIRA, 2006), one that facilitates the process of forming the image, since it as an intangible consumer good, generally presented to consumers by means of descriptions, narrations and photos in the printed and electronic media (BIGNAMI, 2002), such as newspapers, magazines, billboards, radio, television, telephone and the Internet, with the aim of attracting consumers (KOTLER et al., 2006). The 
Internet has become one of the main ways of promoting tourist destinations, by informing potential customers about the attractions available to tourists (BELDONA; CAI, 2006; KAPLANIDOU; VOGT, 2006; GOVERS; GO; KUMAR, 2007).

Worried about the sustainability of destinations, the World Tourism Organization (UNWTO, 2011) has started to pay more attention to the supply of sustainable products. In the late 1990s, its representatives expressed concern for the establishment of an equitable, responsible and sustainable global tourism industry, in shared benefit to all sectors of society. For this purpose, it prepared a set of principles and standards of conduct, forming a Global Code of Ethics for Tourism. It also urges that good practices be disclosed to heighten the awareness of visitors.

To enhance the results of efforts to reduce the environmental impacts on tourist destinations caused by visitors, it is important to understand how consumers react to the sustainability actions and identity established according to the various characteristics of tourist destinations. In light of these aspects and considering that many consumers use the Internet to obtain information before deciding to visit a destination, we formulated the following research question: Is the identity of a tourist destination, as presented at its official website, based on sustainability characteristics associated with a more positive assessment and stronger intention of consumers to visit?

After contextualizing the research problem, the next section presents a review of the literature on the theme and the method of investigation used. Then we describe and analyze the results, before presenting our conclusions in the last section.

\section{CONSUMERS' BEHAVIOR WITH RESPECT TO ENVIRONMENTAL AND SUSTAINABILITY QUESTIONS}

Due to the various discussions about sustainability and the environment among scientists and other experts, environmental awareness has germinated in society at large. As a consequence, consumers are increasingly influenced by these questions in their buying decisions. Many studies have investigated people's buying habits regarding ecologically correct products and aspects of environmental preservation and sustainability (HERBERGER, 1975; TUCKER, 1980; MARTIN; SIMINTIRAS, 1995; LEE; HOLDEN, 1999; CHEN; CHAI, 2010; OKADA; MAIS, 2010; HANSS; BÖHN, 2012), their profile considering demographic and psychographic variables, (KINNEAR et al., 1974; AAKER; BOGAZZI, 1982; HUME et al., 1989; SAMDAHL; ROBERTSON, 1989; ZIMMER et al., 1994; ROBERTS, 1996; ROBERTS; BACON, 1997; AWAD, 2011; PINTO et al., 2011) and their 
actions and attitudes toward consumption (LEE; HOLDEN, 1999; OKADA; MAIS, 2010; ROBINOT; GIANNELLONI, 2010).

Over the past two decades, a recurring finding in the popular management literature has been that consumers' attitudes and buying behavior are influenced by ecological and sustainability questions, such as the production of products and rendering of services in ecologically sustainable form (PEREIRA; AYROSA, 2004). It is common to read that companies that do not properly address environmental questions risk losing the trust of their customers and that the "green" attributes of products can influence purchasing decisions (OTTMAN, 1994; LEE et al., 2010). In an article in a mainstream Brazilian business magazine, Cardozo (2003) considered that ecological marketing contributes to strengthen brand image and boost sales. Trevisan (2002) reached the same conclusion, stating that many consumers prefer products made by companies that express a commitment to the environment.

Although we identified only a few studies focusing specifically on the behavioral aspects of sustainable consumption related to tourism or some associated service, those that analyze consumers' attitudes generally say something about the way consumers behave in relation to sustainability questions, mainly environmental ones. For example, Manaktola \& Jauhari (2007) investigated the attitudes and behavior of consumers with respect to green practices in the Indian hotel sector. The authors demonstrated that consumers are more likely to buy services from hotel operators that develop environmentally sustainable actions as long as the cost is not higher. The consumers surveyed were found to make choices based on the combination of attributes that best meets their needs. Besides this, the authors found that attributes that differ from the basic ones can add value to the business.

In turn, Okada \& Mais (2010) also found that individuals are more sensitive to environmental and sustainability questions, but unlike Manaktola \& Jauhari (2007), they found that people are willing to pay more for green products and services. The objective of their study was to verify how consumers respond to ecologically based alternatives, to enable managers to better position their green products with prices that consumers are willing to pay. The results showed that positive framing (focusing on the advantages of the green product) works best for environmentally conscious consumers, while negative framing (with focus on how to avoid the disadvantages on non-green products) works better among less conscious consumers. 
Chen \& Chai (2010) compared the effect of gender on attitudes toward the environment and green products and also the relationship among attitudes, environment and green products. The results indicated the existence of significant differences between the sexes regarding ecological attitudes. As would be expected, there are theoretical indications that consumers who are more sensitive to environmental or green questions tend to behave more favorably to ecological and sustainability questions (OKADA; MAIS, 2010). For example, Roberts (1996) sought to identify consumer types and characterize them according to their demographic traits. The author proposed the "environmental concern" (EC) scale, which has subsequently been used by other researchers to characterize the profile of ecologically conscious consumers (E.G., STRAUGHAN; ROBERTS, 1999; LAGES; NETO, 2002; BEDANTE, 2004).

According to Lacher (2012), the demand for vacation options oriented to sustainability is rising, a trend that due to the fact that consumers are becoming increasingly conscious of the negative effects that trips can generate at the destinations. His study aimed to assess the preferences of consumers for different types of sustainable tourism certifications and also to identify if these certifications are relevant to tourists. The results indicated that the majority of consumers prefer certifications focused on environmental protection and that more stringent certifications provide little additional utility to consumers. The author also observed that tourist activity, when structured with sustainability principles, can motivate tourists and generate positive effects on their preferences and choices (LACHER, 2012).

Based on these and other studies in this area, the UNWTO (2011) considered that the motivation and behavior of tourists can be increasingly characterized by selectivity in choosing destinations, sensitivity to the environment and local culture, economic and social considerations and the expected quality of the experience. Considering then, that previous studies have theorized and empirically found that consumers tend to present more positive attitudes and buying intentions in relation to products and services that have sustainable and environmentally correct characteristics, we framed the following hypothesis: H1: Consumers will have positive attitudes toward travel destinations that stress questions of sustainability at their websites.

\section{IDENTITY AND IMAGE OF TOURIST DESTINATIONS}

Although academic studies of brand identity related to products and services date back to the 1970s (MARGULEIS, 1977), those focusing on the branding of tourist destinations only began in the past decade (CAI, 2002). Despite some skepticism about transferring the 
traditional concept to this new context (O'SHAUGHNESSY; O'SHAUGHNESSY, 2000), this perspective has attracted a good deal of attention from researchers and professionals in the tourist marketing area. Although the study of the identity of tourist destinations at first glance appears to be relatively recent (BARRE, 2012; CARVALHO, 2012), the topic has been partially covered under the alternative label of studies related to the image of destinations for more than 30 years (HUNT, 1975; GALLARZA; SAURA; GARCIA, 2002; LEE et al., 2010; PINTO et al., 2011).

Organizational identity has been defined as being composed of the lasting characteristics that distinguish one organization from others (ALBERT; WHETTEN, 1985; DHALLA, 2007). The majority of studies on organizational identity have been based on social identity, such as that of Albert \& Whetten (1985). The authors define this construct as a question of self-reflection of the company, based on three traits: centrality, distinctiveness and continuity. Therefore, organizational identity contributes to the specificity and uniqueness of an organization.

Due to our objective, here we focus specifically on projected identity. The concept of projected identity includes corporate identity, considered as the visual tradition that translates into what an organization is. But it also incorporates all the discourse of senior management about what the organization stands for, which can be expressed by institutional folders, CDROMs, the website, internal newsletters and/or magazines, presentations, press releases, advertisements and institutional promotional campaigns, among the various communications means and actions adopted by the organization as a way to position itself internally and externally (ALMEIDA, 2005; HARISH, 2010).

Unlike the image of conventional products, the brand of a travel destination has various distinct characteristics, so they can be considered compound products resulting from a combination of diverse elements (HARISH, 2010). The products and services provided by companies are meant for sale to generate profits and increase the firm's market value. From this perspective, those related to tourist destinations are created to increase the economic prosperity of people, by means of generating jobs, and to sustain local economies. The identity of a destination, characterized by its brand, is important because potential visitors can make their decisions also considering the trust built by the perception and experience when visiting the place (MIHAILOVICH, 2006).

Based on the above, we believe that potential tourists who intend to travel are influenced by narratives and images projected in the media. This happens because tourism is a 
predominantly intangible consumer good and what induces consumers to purchase it are the promises of satisfaction the destination can offer (BIGNAMI, 2002; DAY; SKIDMORE; KOLLER, 2002) and consumers' motivation for the trip. Therefore, the formation of a destination's identity is an important step for its sustainability. This leads to our second hypothesis: H2: The identity of a tourist destination presented at its website, managed by means of sustainability elements, contributes to the formation of a positive image of the locale.

\section{WEBSITES: IDENTITY TOOL OF TOURIST DESTINATIONS}

Companies involved in tourism are among the largest service providers in the world. With increasing demand, this sector is among the most prosperous of the e-commerce sector, and information technology over the Internet can add value to these services and facilitate dissemination of information to consumers (NYSVEEN; METHLIE; PEDERSEN, 2003; LEE; CAI; O'LEARY, 2006). Indeed, the virtual environment has become the main means of marketing tourism (KIM; FESENMAIER, 2008).

The Internet has transformed tourist activity, modifying the way products are presented, how services are rendered, as well as the form of sale and communication, due to the ease of access (BALANZÁ; NADAL, 2003). According to Williams \& Palmer (1999), even at the time of that writing a good part of travelers used virtual platforms for research and buying. Corroborating this idea, Nysveen, Methlie \& Pedersen (2003) state that the Internet is a good way for companies involved in tourism to generate value for their customers and strengthen their image.

With the growing importance of websites for tourist activity, the theme has increasingly attracted the attention of researchers (BUHALIS; DEIMEZI, 2004; SKADBERG; KIMMEL, 2004; GOVERS; GO; KUMAR, 2007; FRIAS; RODRIGUEZ; CASTANEDA, 2008; MORRISON; TAYLOR; DOUGLAS, 2004; BAI; LAW; WEN, 2008). RECENTLY; CHAIPRASIT et al. (2011) surveyed the expectations and preferences of potential tourists in Thailand with respect to travel websites. The results indicated there were no significant differences in the respondents' site preferences, and that tourists prefer to have more and better information than greater functionality of the site, meaning more reliable, current and useful information on the products and services available at the destination. The authors also concluded that companies should manage their websites so as to provide this type of information, since the Internet is one of the main ways potential tourists search for information before making travel decision, corroborating the previous ideas of Chon (1991). 
Choi, Lehto \& Morrison (2007) perceived that access to the websites of tourist destinations is concentrated in the first moments, suggesting the importance of initial page in the process of image formation and choices of tourists. Therefore, it is reasonable to expect websites to be an important tool for managing the identity of tourist destinations regarding sustainability aspects, since they help consumers form their image of the place when searching for information. Based on this, we formulated the following hypothesis: H3: Consumers or more likely to visit a tourist destination that presents sustainability characteristics at its website. Figure 1 below shows the proposed theoretical structure, demonstrating the relationship between the independent variables (sustainability characteristics forming the identity) and dependent variables.

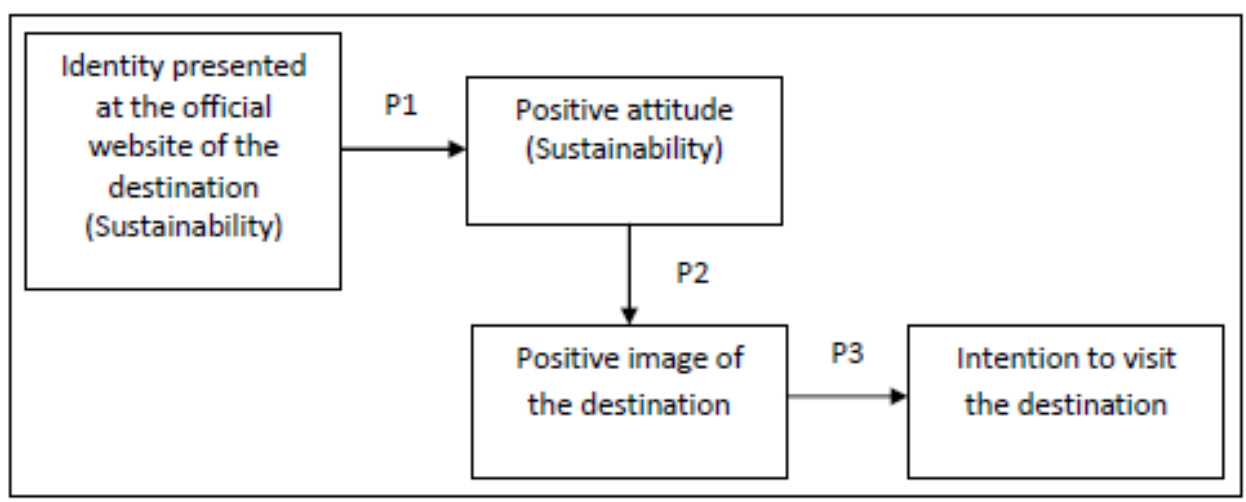

Figure 1: Diagram of the proposed theory.

Source: Authors.

\section{METHODOLOGICAL PROCEDURES}

This study is explanatory in nature, since its investigates the causal relations identified from a review of the existing theory (HULLAND; CHOW; LAM, 1996; AAKER; KUMAR; DAY, 2001; MALHOTRA, 2006; CORRAR; PAULO; DIAS FILHO, 2007; LATTIN; CARROLL; GREEN, 2011). To do this we set up quasi-experiment.

Despite some criticisms, such as the impossibility of configuring a laboratory without interference of outside variables and the fact the participants are not experiencing something real at the moment of study, this experimental method is generally accepted in academia and is commonly used in the areas of management and psychology (E.G., COHEN; LEDFORD, 1994; GRANT; HOFMANN, 2011) as well as in marketing studies (DEBRUYNE; FRAMBACH; MOENAERT, 2010). More specifically, quasi-experiments have been widely applied to analyze consumers' attitudes toward environmentally correct products (SERPA; ALVES, 2000; PEREIRA; AYROSA, 2004; VELTER et al., 2009). Here we expand this to the area of tourist services. 
The universe considered for this study was all possible consumers of tourist services, here considered to be infinite. Due to the non-probabilistic selection criterion, the number of respondents was based on practical rules (HAIR et al., 2006) and on observation of the average sample sizes in previous studies. In this respect, based on some field studies in the marketing area (SERPA; AVILA, 2000; PEREIRA; AYROSA, 2004), we decided on a minimum of 60 respondents per group, so as to assure at least 100 valid questionnaires would be completed. According to Hair et al. (2006), Malhotra (2006) and Lattin, Carroll \& Green (2011), at least 50 respondents are necessary for application univariate and multivariate analyses. In light of these orientations, we gathered data from 12 experimental sessions in January 2012. At the end of the treatment and validation process, there were 279 valid questionnaires, 145 from the experimental group (EG) and 134 from the control group (CG).

\subsection{RESEARCH SCENARIOS}

We presented four scenarios, two to the control group and two to the experimental group. The first group observed images of the official portals of tourist destinations in their original format, while the second group observed a modified version of the sites, containing added information on sustainability and highlighting sustainability actions equally for each destination (sustainability initiatives of the country).

The websites were the official tourism portals of Brazil (http://www.braziltour.com/) and Holland (http://www.holland.com/global/Tourism.htm). The Netherlands, or Holland, is an important traditional trading partner of Brazil, currently the sixth most important, behind China, United States, Argentina, Germany and Japan. In Latin America, Brazil is the most important trading partner and target for investments of Holland (TAMOTO, 2012), making the choice of the two countries relevant. Also, both countries have shown concern for the sustainability of their tourist destinations, although Holland is far ahead of Brazil in this respect. On the other hand, the Brazilian government has been particularly stimulating internal tourism in recent years, including efforts to learn through surveys if sustainability can influence the opinions of potential tourists. The use of these official portals in the laboratory enabled the participants to experience a real situation of analyzing a tourist destination by means of the website, assuring the quality of the study.

The dimensions included in the EG scenario were those established by the UNWTO (1993), considered as necessary for sustainable development of tourism, stressing the question of the environment integrated with economic sustainability. These dimensions are social and cultural sustainability, economic and political sustainability, and environmental sustainability. 
The sustainability argument added to the official websites for the treatment group was developed by a web designer with our help, based on the dimensions presented, and was composed of texts and images. The information was inserted in the websites with the help of a graphic manipulation program. After examining the portals, the respondents filled in a questionnaire with the scores attributed to the dependent and independent variables.

\subsection{VARIABLES, INSTRUMENT AND DATA COLLECTION}

The independent variable was sustainability, defined as the equitable distribution of natural resources between different generations, centered on social equality, cultural diversity, economic efficiency and protection of the environment (UNWTO, 2003; CIEGIS; CIEGIS; JASINSKAS, 2005). Sustainability in this study was composed of the dimensions established by the UNWTO (2003). The minimum number for manipulation is two, i.e., presence/absence of the independent variable (SAMPIERI et al., 2006), which we adopted in this study. The websites used in the quasi-experiment did not originally contain information related to sustainability on the three pages selected, and these were the pages observed by the control group. In turn, the experimental group viewed the pages modified with figures and texts conveying aspects of sustainability.

There were four dependent variables: positive attitude toward the identity associated with sustainability presented by the destination's website; positive image of the tourist destination (country); intention to visit the destination (country); and level of environmental awareness.

The respondents were asked to fill in a questionnaire, developed based on the theoretical study, divided into three parts. The first was prepared employing the scale proposed by Byon $\&$ Zhang (2010). They developed this scale to verify how the image of a destination affects the consumption of tourist-related services. In the present study, we used this scale as a general indicator of formation of the image of the destination, with some modifications due the specificities of the study. The opinion of the respondents was measured on a Likert scale of five points (MALHOTRA, 2006): 1 for "totally disagree"; 2 for "disagree somewhat"; 3 for "neutral", 4 for "agree somewhat"; and 5 for "totally agree".

To discover the level of environmental concern of the participants, the second part of the questionnaire used the environmental concern (EC) scale proposed by Roberts (1996). Besides the scales to measure the dependent variables, the third part of the questionnaire was composed of nine closed questions to obtain demographic information and questions to indicate the groups' attitudes. These last items were included to observe the participants' past 
vacation travel experience, preferred destinations, sources of travel information and evaluation of the websites.

The scale was established after testing of adherence and reliability (AAKER; KUMAR; DAY, 2001; MALHOTRA, 2006). We also tested the data for normality, calculated Cronbach's alpha and ran tests of the means, finalized by multivariate analysis of the descriptive statistics and tests of the hypotheses. To assess the validity, we carried out a theoretical comparison (theoretical articulation with the findings), to identify a convergent or divergent validity in relation to what other results have indicated (COOPER; SCHINDLER, 2003). The data were collected by two researchers over a period of 15 days, in 12 experimental sessions of 30 minutes each, following the same procedures and standards established for constitution of the laboratory in the planning stage.

\section{RESULTS AND ANALYSES}

The composition of the sample by sex was $35.8 \%$ men and $64.2 \%$ women. Regarding living place, $97.4 \%$ of the respondents were residents of the Fortaleza metropolitan region (state of Ceará, northeastern Brazil). The sample was evenly divided between married (45.5\%) and single (46.6\%) people. The average monthly household income was $\mathrm{R} \$ 4,486.00$, with a standard deviation of $\mathrm{R} \$ 3,663.19$. The mean age was approximately 34 years. With respect to travel habits, $67.7 \%$ of the respondents stated they had the habit of traveling during vacation periods or over long holiday weekends (with travel in Brazil being most common, at $76 \%$ ). Regarding the source of finding information about tourist destinations, $75.6 \%$ said they used the Internet. Finally, with respect to domestic versus foreign travel, $72.2 \%$ stated they preferred to travel in Brazil.

Analysis of the two samples of the EG (76 Brazil and 69 Holland) showed that the average age, city of residence and schooling were similar between the two subgroups. On the other hand, the participants shown the Brazilian portal had higher household income and travel frequency than those who were shown the Dutch website. Both subgroups preferred to travel in Brazil and sought information from the Internet, particularly those that analyzed the Dutch site. For the CG (66 Brazil and 68 Holland), the demographic profiles and some characteristics were similar to those of the EG (see Table 1). 
Table 1 - Comparison of the profiles of the groups

\begin{tabular}{l|c|c}
\hline \multicolumn{1}{c|}{ Characteristic } & EG Brazil & EG Holland \\
Gemder - Male | Female & $42.1 \% \mid 57.9 \%$ & $33.3 \% \mid 66.7 \%$ \\
Marital status - Single | Married & $44.7 \% \mid 47.4 \%$ & $46.4 \% \mid 42.0 \%$ \\
Age range - 26 to 40 years & $63.2 \%$ & $68.1 \%$ \\
City of residence - Fortaleza & $94.7 \%$ & $88.4 \%$ \\
Schooling - University degree & $100.0 \%$ & $98.6 \%$ \\
Income - R \$ 2,161.00 to R\$ 8,640.00 & $72.8 \%$ & $53.6 \%$ \\
\hline
\end{tabular}

To test the adherence of the sample, we used the Kolmogorov-Smirnov (K-S) test, as recommended by Malhotra (2006). This test was used to calculate the level of significance of the differences between the distributions of the scales regarding image of the destination and travel intention (15 items), as well as environmental awareness (12 items) in relation to the normal distribution. Besides these, we analyzed the scales reflecting such aspects as travel habits, preference for destinations, source of information and evaluation of the portals. The result was significant (sig. 0.000) for all the scales analyzed, considering the entire sample and each group, with rejection of the null hypothesis of normal distribution for all the variables tested. In such cases, the use of parametric techniques is not recommended, so we used nonparametric techniques (AAKER; KUMAR; DAY, 2001; MALHOTRA, 2006; CORRAR; PAULO; DIAS FILHO, 2007; LATTIN; CARROLL; GREEN, 2011).

To obtain a better understanding of the behavior of the scale, to assure the reliability of the data, we calculated Cronbach's alpha, which measures the internal consistency of multiple scales (MALHOTRA, 2006; Hair et al., 2006). In this survey we used only one Likert scale, with five points. The tests presented results above 0.6, which according to Hair et al. (2006) is the threshhold for satisfactory reliability. Therefore, the results obtained - positive image of the destination $(\alpha=0.861)$, positive attitude toward sustainability $(\alpha=0.838)$ and intention to visit the destination $(\alpha=0.669)$ - were all satisfactory. The result for the environmental awareness scale was also satisfactory $(\alpha=0.664)$. In the factor analysis, the Kaiser-MeyerOlkin (KMO) test produced a coefficient of 0.855 and the Bartlett test of sphericity presented a chi-squared result of 1656.056 with 105 degrees of freedom and significance of $p<0.000$, indicating the possibility of using this method. For all the groups, the results of the scale were confirmed, corroborating the results of Byon \& Zhang (2010) (see Table 2).

In studies of attitudes toward sustainability and the environment it is necessary to check the sensitivity of the participants regarding these questions. In our sample, $54.8 \%$ of the 
participants indicated they were sensitive to sustainability aspects. Therefore, it was necessary to verify whether this declared environmental concern had some influence on these participants' attitudes in the evaluation of the destinations and intention to purchase tour packages via the websites. For this purpose we performed multiple regression analysis with all 279 participants and then separately for each group, considering all the items of the scales.

Table 2 - Factor loadings, Cronbach's alpha and means of the groups

\begin{tabular}{|c|c|c|c|c|c|c|}
\hline \multirow[t]{2}{*}{ Variable } & \multirow{2}{*}{$\begin{array}{l}\text { Factor } \\
\text { Loading }\end{array}$} & \multirow{2}{*}{$\begin{array}{l}\text { Cronbach's } \\
\text { Alpha }\end{array}$} & \multicolumn{2}{|c|}{$\begin{array}{l}\text { Mean (std. dev.) - } \\
\text { Brazil }\end{array}$} & \multicolumn{2}{|c|}{$\begin{array}{l}\text { Mean (std. dev.)- } \\
\text { Holland }\end{array}$} \\
\hline & & & EG & CG & EG & CG \\
\hline Image of the destination & & 0.861 & & & & \\
\hline It's a pleasant tourist destination. & 0.738 & & $\begin{array}{l}4.27 \\
(0.79)\end{array}$ & $\begin{array}{l}4.37 \\
(0.72)\end{array}$ & $\begin{array}{l}4.05 \\
(0.78)\end{array}$ & $\begin{array}{c}4.29 \\
(0.67)\end{array}$ \\
\hline The country has beautiful scenery. & 0.772 & & $\begin{array}{c}4.43 \\
(0.74) \\
4.13\end{array}$ & $\begin{array}{c}4.60 \\
(0.74) \\
4.18\end{array}$ & $\begin{array}{c}4.13 \\
(0.64) \\
3.52\end{array}$ & $\begin{array}{c}4.32 \\
(0.63) \\
3.66\end{array}$ \\
\hline The country has a good climate. & 0.646 & & $(0.85)$ & $(0.82)$ & $(0.80)$ & $(0.89)$ \\
\hline The country offers interesting & & & 3.77 & 4.10 & 3.69 & 4.01 \\
\hline cultural events. & 0.678 & & $(0.96)$ & $(0.91)$ & $(0.71)$ & $(0.70)$ \\
\hline The country has beautiful natural & & & 4.42 & 4.33 & 3.94 & 4.08 \\
\hline attractions. & 0.737 & & $(0.75)$ & $(0.81)$ & $(0.64)$ & $(0.86)$ \\
\hline The country is suitable for a good & & & 4.26 & 4.45 & 3.86 & 4.19 \\
\hline vacation. & 0.750 & & $(0.82)$ & $(0.64)$ & $(0.75)$ & $(0.74)$ \\
\hline It's a destination for a memorable & & & 4.06 & 4.39 & 3.60 & 3.94 \\
\hline trip. & 0.773 & & $(0.85)$ & $(0.78)$ & $(1.00)$ & $(0.91)$ \\
\hline The country offers interesting & & & 3.77 & 4.09 & 3.88 & 3.94 \\
\hline historical attractions. & 0.630 & & $(0.93)$ & $(0.82)$ & $(0.83)$ & $(0.88)$ \\
\hline Positive attitude(sustainability) & & 0.838 & & & & \\
\hline $\begin{array}{l}\text { The country develops } \\
\text { environmentally correct practices }\end{array}$ & 0.811 & & $\begin{array}{l}3.16 \\
(1.05)\end{array}$ & $\begin{array}{l}2.91 \\
(0.97)\end{array}$ & $\begin{array}{c}3.97 \\
(0.80)\end{array}$ & $\begin{array}{l}3.66 \\
(0.94)\end{array}$ \\
\hline The country is concerned with & & & 3.12 & 3.15 & 3.74 & 3.78 \\
\hline cultural and social questions. & 0.829 & & $(1.02)$ & $(0.97)$ & $(0.65)$ & $(0.82)$ \\
\hline The country is concerned with & & & 3.29 & 3.09 & 3.90 & 3.62 \\
\hline sustainability questions. & 0.870 & & $(1.04)$ & $(0.95)$ & $(0.71)$ & $(0.86)$ \\
\hline The country promotes economically & & & 2.95 & 2.97 & 3.46 & 3.49 \\
\hline feasible actions. & 0.773 & & $(0.86)$ & $(0.72)$ & $(0.74)$ & $(0.76)$ \\
\hline Intention to visit & & 0.669 & & & & \\
\hline $\begin{array}{l}\text { Sustainability actions are important } \\
\text { to my choice of a vacation }\end{array}$ & & & 3.97 & 3.80 & 4.00 & 3.99 \\
\hline destination. & 0.820 & & $(0.94)$ & $(0.88)$ & $(0.84)$ & $(1.03)$ \\
\hline $\begin{array}{l}\text { I recommend countries that promote } \\
\text { sustainability actions to }\end{array}$ & & & & & & \\
\hline acquaintances who ask for travel & & & 3.53 & 3.59 & 3.74 & 3.91 \\
\hline advice. & 0.840 & & $(1.06)$ & $(0.88)$ & $(0.87)$ & $(0.97)$ \\
\hline $\begin{array}{l}\text { I intend to visit some cities of this } \\
\text { country. }\end{array}$ & Excluded & & - & - & - & - \\
\hline
\end{tabular}

Table 3 shows that the independent variables (overall image of the destination, sustainability image and intention to visit) explained only $9.6 \%$ of the variation of the dependent variable (environmental concern). The result of the F-test and the other tests did not demonstrate significance (sig. 0.345). 
Similar to these results, the analyses of each group also did not present statistical significance to enable making precise inferences. In this sense, based on the analyses, we believe that the variations in environmental the concern (sensitivity) of these participants had little influence on their responses. In studies of the profile of ecologically correct conseumers, the environmental concern scale generally has little explanatory power on variations in the ecological awareness of individuals (E.G., ROBERTS, 1996; ROBERTS; BACON, 1997; STRAUGHAN; ROBERTS, 1999). A recurring question in studies trying to identify the profile of these consumers is the absence of a direct relationship between environmental concern (ecological awareness) and the purchase of products and services. In this respect, our results corroborate earlier findings (SCHLEGELMILCH et al., 1996; YAMTANG; CHAN, 1998). In other words, for this situation of evaluation and intention to visit a tourist destination, the environmental concern of the participants did not have a relevant relationship with their responses.

\begin{tabular}{c|c|c|c|c|c|c}
\multicolumn{7}{c}{ Table 3 - Multiple regression for the level of environmental concern } \\
\hline $\mathrm{R}$ & $\mathrm{R}^{2}$ & Adjusted $\mathrm{R}^{2}$ & Estimated Error & $\mathrm{F}$ & Sig. F & Durbin-Watson \\
& & & & & & \\
\hline 0.309 & 0.096 & 0.009 & 5.030 & 1.108 & 0.345 & 1.824 \\
\hline
\end{tabular}

After these analyses, we cross-referenced some demographic characteristics against the participants' environmental concern, to shed more light on these consumers of tourism services. For example, regarding age range, people older than 30 tended to be more concerned with environmental questions than those under 30. With respect to household income, those with higher monthly earnings (above $\mathrm{R} \$ 2,100.00$ ) tended to be more worried than those receiving less income.

We also investigated whether the frequency of travel influence the level of environmental concern regarding the destinations, i.e., whether those who travel more differed from those travel on this question. The result was not statistically significant (sig. 0.426), suggesting no relation among the respondents between the number of past vacation trips and the level of environmental concern. Again we carried out this analysis in general and with the different groups, and the results of the groups in stratified form presented the same tendency for both groups.

The results of the tests of normality, presented previously, indicated the most suitable test to compare the means as the Mann-Whitney U-test (MALHOTRA, 2006; HAIR et al., 2006). It is a statistical test for a variable measured on an ordinal scale that compares the 
difference in the position of two populations based on observations of two independent samples (MALHOTRA, 2006).

The hypothesis tests were carried out considering the groups that evaluated the official website of Brazil and of Holland. Since the results were for the most part similar, in the following discussion we present the outputs of the tests considering the analyses of the two distinct groups, highlighting the relevant differences observed for each group. For the first hypothesis, the results for those who observed the Brazilian website did not provide a base to conclude that the samples of both groups belonged to different populations, according to the results of the statistical significance. On the other hand, these results were positive for those who observed the Dutch website. Although significant, the results of the z-score (-1.666) did not present relevant differences in the table to find differences in the samples of the EG that analyzed the Dutch website. Therefore, based on the set of data, hypothesis H1 was not supported. This suggests that consumers do not have stronger positive attitudes in the evaluation of destinations that emphasize sustainability questions in their promotion via websites (see Table 4).

With hypothesis $\mathrm{H} 2$ we sought to verify whether the identity of a tourist destination presented at its website, managed by means of sustainability elements, contributes to the formation of a more positive image of the location. For the group that evaluated the Brazilian portal, the variables "the country offers interesting cultural events", "it's a destination for a memorable trip" and "the country offers interesting historical attractions" were statistically significant. However, these variables are part of a multiple scale, and for the validity of the test the vectors of the means of multiple dependent variables of each group must be considered (MALHOTRA, 2006; HAIR et al., 2006). In this respect, it is not possible to make inferences about these results, mainly when considering the results of the test for the group that analyzed the Dutch portal, which were not relevant. Therefore, $\mathrm{H} 2$ also was not supported.

The aim of H3 was to know whether consumers are more likely to visit a tourist destination that presents sustainability characteristics at its website. In the items of the intention scale used (BYON; ZHANG, 2010), the outputs of the tests also did not allow concluding that the samples did not present different responses. In this sense, according to the statistical significance results reported in Table 4, hypothesis H3 was also not supported. 
Table 4 - Results of the hypothesis tests for the groups evaluating the Brazilian and Dutch websites

\begin{tabular}{l|c|c|c|c|c|c}
\hline \multirow{2}{*}{\multicolumn{1}{c}{ Constructs }} & \multicolumn{2}{|c|}{ Brazilian Website Group } & \multicolumn{3}{c}{ Dutch Website Group } \\
\cline { 2 - 7 } & $\begin{array}{c}\text { Mann- } \\
\text { Whitney U }\end{array}$ & $\mathbf{Z}$ & Sig. & $\begin{array}{c}\text { Mann- } \\
\text { Whitney U }\end{array}$ & $\mathbf{Z}$ & Sig. \\
\hline Positive image of the destination & 2101.000 & -1.666 & 0.096 & 1696.000 & -2.798 & 0.005 \\
Positive attitude (sustainability) & 2399.000 & -0.447 & 0.655 & 2090.000 & -1.106 & 0.269 \\
Intention to visit the destination & 2271.500 & -0.975 & 0.330 & 2093.500 & -1.096 & 0.273 \\
\hline
\end{tabular}

As seen previously, even though there have been few studies of the behavior of consumers with respect to formation of the sustainability identity of tourist destinations via websites, it was possible to observe some contrary relations between studies that have investigated consumers' attitudes regarding environmental and sustainability questions. For example, Manaktola \& Jauhari (2007) and Okada \& Mais (2010) demonstrated that consumers are more likely to purchase products and services from companies that engage in environmentally friendly and sustainability actions. However, other studies have found that consumers do not believe these aspects are relevant for positive assessment and choice (BANSAL; ROTH, 2000; CHEN; CHAI, 2010; LAGES; NETO, 2002; ROCHA, 2007; ROCHA; SANTOS, 2007; ROCHA, 2011), mainly when evaluating tourist destinations via websites.

\section{CONCLUSIONS}

Sustainability associated with tourism has been relevant for management of tourist destinations over the past four decades. For this reason, theoreticians tend to affirm that these aspects influence people's attitudes in their buying decisions. Particularly since the turn of the century, individuals' behavior with respect to consumption of goods and services has been changing.

Although some researchers have considered that sustainability questions can be a relevant attribute for consumers, some evidence shows that the relations between the sustainability of a destination and buying intentions (particularly willingness to pay more for environmentally correct products and services) are still evolving. For this reason, to date there is still little alignment of the findings of empirical research, making the discussion difficult. Besides this, during our review of the theoretical literature, we did not identify any studies with similar purpose that have employed the same or similar variables to those applied here. For this reason, we believe this study can help understanding of the theme and add to studies of the consumer behavior regarding sustainability questions.

We found that the Internet really is a relevant tool for the tourist sector and that its functionality has transformed management of this activity, modifying the way tourist products 
are presented and supplied, as well as the form of marketing and communication (BALANZÁ; NADAL, 2003; HARISH, 2010). Nowadays a large portion of travelers use virtual platforms for research and purchasing.

Before analyzing the hypotheses, we sought to verify whether the environmental concern of the participants could influence their evaluation of the destinations and intention to purchase travel services by means of the websites. However, even though nearly half of the participants stated they are sensitive to these questions, their level of environmental awareness (sensitivity) had little influence on their responses. The studies of Roberts (1996), Satraugh \& Roberts (1999), Lages \& Neto (2002) and Bedante (2004), for example, contained few dependent variables that explain the behavior of environmentally conscious consumers, and those that appeared had little influence on the responses. Perhaps consumers are still in a transition phase in their behavior regarding sustainability questions. We also observed that the participants older than 30 years, as well as those with higher incomes, tended to be more concerned with environmental questions.

Considering the averages of the assessment for formation of a positive image and the attitude toward sustainability in the two treatment groups, the websites were positively evaluated by the respondents, with higher averages in the control groups. For all groups the evaluation was relatively high, but for those that observed the Dutch website, the sustainability attribute received higher evaluations. With respect to the attitude scale regarding sustainability, the experimental group demonstrated a better evaluation on the items where the respondents indicated whether the country, based on the website, is concerned and develops sustainable and environmentally correct actions. However, significant differences $(p<0.05)$ were only observed for the participants who evaluated the Dutch website. Despite some differences in the results, it was not possible to support the hypotheses related to this objective.

Regarding the intention of visiting a tourist destination based on the official website, the participants did not respond positively to sustainability arguments. In other words, there were no significant variations in the responses for all the groups analyzed.

Managing the identity of a tourist destination by means of sustainability characteristics is still not very common. It is important, therefore, to analyze what really should be considered as relevant for a destination to position itself as sustainable by means of economically, socially, culturally and environmentally correct actions. Although according to the results here, consumers do not tend to believe these questions are relevant in choosing a 
vacation spot, we believe those responsible for managing tourist destinations need to adopt ethical postures and responsible practices.

The respondents did not tend to have more positive attitudes about the destinations when sustainability questions were included in the websites, and the inclusion of sustainability elements did not contribute to a more positive image of the locales. Furthermore, according to the results consumers are not more likely to visit a tourist destination that presents sustainability characteristics at its website. These findings run counter to the theoretical proposals found in the literature reviewed, because according to them, sustainability should have been a relevant attribute to form a positive image and increase the propensity to visit the destination. Therefore, we can speculate that individuals who intend to travel for leisure are not concerned with sustainability questions, or at least this attribute is not relevant for the intention to visit a destination and in its positive evaluation.

Finally, the responses to each variable analyzed on the scales were relatively equal for both groups. We cannot say whether this pattern came from the characteristics of the sample surveyed or factors associated with the moment when the participants answered the questionnaire. What stood out was the large number of neutral responses for all the groups. Perhaps a lack of analytic sense of the participants led to this result, since there were many questionnaires filled in mostly with the same responses, as observed in the pre-testing phase. Although it is just an impression, we think it is likely the lack of analytic sense affected the results.

The study has some limitations, which are inherent in a quasi-experiment. We can mention the complexity of maintaining the laboratory in the same conditions for all the respondents and the control of foreign variables. These are issues to address in future studies.

\section{REFERENCES}

AAKER, D., BAGOZZI, R. P. Attitudes toward public policy alternatives to reduce air pollution. Journal of Marketing. v. 1, p. 85-94, 1982.

AAKER, D. A.; KUMAR, V.; DAY, G. S. Pesquisa de marketing. São Paulo: Atlas, 2001.

ALBERT, S.; WHETTEN, D. A. Organizational identity. Research in Organizational Behavior, Greenwich, n. 7, CT: JAI Press, p. 263-295, 1985.

ALMEIDA, A. L. C. A influência da identidade projetada na reputação organizacional. 2005. Tese (Doutorado) - Pós-Graduação e Pesquisas em Administração da Faculdade de Ciências Econômicas, Universidade Federal de Minas Gerais (UFMG), Belo Horizonte, 2005. 
ARANHA, F.; ZAMBALDI, F. Análise fatorial em administração. São Paulo: Cengage Learning: 2008.

AWAD, T. A. Environmental segmentation alternatives: buyers' profiles and implications. Journal of Islamic Marketing, v. 2, n. 1, p. 55-73, 2011.

BAI, B.; LAW, R.; WEN, I. The impact of website quality on customer satisfaction and purchase intentions: evidence from Chinese online visitors. International Journal of Hospitality Management, v. 27, p. 391-402, 2008.

BALANZÁ, I. M.; NADAL, M. C. Marketing e comercialização de produtos turísticos. São Paulo: Pioneira Thomson Learning, 2003.

BALOGLU, S.; McCLEARY, K. W. A model of destination image formation. Annals of Tourism Research, v. 35, p. 868-897, 1999.

BANSAL, P.; ROTH, K. Why companies go green: a model of ecological responsiveness. The Academy of Management Journal, v. 43, n. 4, p. 717-736, ago. 2000.

BARRE, S. de la. Wilderness and cultural tour guides, place identity and sustainable tourism in remote areas. Journal of Sustainable Tourism, iFirst, p. 1-20, 2012.

BEDANTE, G. N. A influência da consciência ambiental e das atitudes em relação ao consumo sustentável na intenção de compra de produtos ecologicamente embalados. Dissertação (mestrado) - Programa de Pós-graduação em Administração, Universidade Federal do Rio Grande do Sul, Porto Alegre (RS), 2004.

BELDONA, S.; CAI, L. An exploratory evaluation of rural tourism websites. Journal of Convention \& Event Tourism, v. 8, n. 1, 2006.

BIGNAMI, R. A imagem do brasil no turismo. São Paulo: Editora Aleph, 2002.

BUHALIS, D.; DEIMEZI, O. E-tourism developments in Greece: information communication technologies adoption for the strategic management of the Greek tourism industry. Tourism and Hospitality Research, n. 5, v. 2, p. 103-130, ago. 2004.

BYON, K. K.; ZHANG, J. J. Development of a scale measuring destination image. Marketing Intelligence \& Planning, v. 28, n. 4, p. 508-532, 2010.

CAI, L. A. Cooperative branding for rural destinations. Annals of Tourism Research. v. 29, n. 3, 2002.

CARDOZO, J. S. Geração de valor e marketing social. Valor Econômico, 4, n. 712, mar. 2003. Disponível em:

<http://www.valoronline.com.br/valoreconomico/materia.asp?id=1699967>. Acesso em: 21 dez. 2011.

CARVALHO, A. L. P. Quadros sedutores no campo do turismo e mídia: a construção da identidade paraibana pela mídia turística. Revista Iberoamericana de Turismo - RITUR, Penedo, v. 2, n. 1, p. 36-57, 2012. 
CHAIPRASIT, K. et al. Tourist expectations toward travel and tourism websites in Thailand. The International Business \& Economics Research Journal, v. 10, n. 3, p. 41, mar. 2011.

CHEN, T. B.; CHAI, L. T. Attitude towards the environment and green products: consumers' perspective. Management Science and Engineering, v. 4, n. 2, 2010.

CHOI, C.; LEHTO, X.; MORRISON, A. Destination image on the web: content analysis of Macau travel related websites. Tourism Management, v. 28, n. 1, p. 118-129, 2007.

CHON, K. S. Tourism destination image modification process: marketing implications. Tourism Management, mar. 1991.

CIEGIS, R.; CIEGIS, R.; JASINSKAS, E. Concepts of strong comparability and commensurability versus concepts of strong and weak sustainability. Inzinerine EkonomikaEngineering Economics, v. 5, p. 31-35, 2005.

COHEN, S. G; LEDFORD JUNIOR, G. E. The effectiveness of self-managing teams: a quasi-experiment. Human Relations, v. 47, n. 1, p. 13-43, 1994.

COOPER, C. The environmental consequences of declining destinations. Progress of Tourism and Hospitality Research, v. 2, p. 337-345, 1996.

COOPER, D. R.; SCHINDLER, P. Métodos de pesquisa em administração. 7. ed. Porto Alegre: Bookman, 2003.

CORRAR, L. J.; PAULO, E.; DIAS-FILHO, J. M. Análise multivariada: para os cursos de administração, ciências contábeis e economia. São Paulo: Atlas, 2007.

CROMPTON, J. L. An assessment of the image of Mexico as a vacation destination. Journal of Travel Research, v. 17, p. 18-23, 1979.

DAY, J.; SKIDMORE, S.; KOLLER, T. Image selection in destination positioning: a new approach. Journal of Vacation Marketing, v. 8, n. 2, p. 177-186, 2002.

DEBRUYNE, M.; FRAMBACH, R. T.; MOENAERT, R. Using the weapons you have: the role of resources and competitor orientation as enablers and inhibitors of competitive reaction to new products. The Journal of Product Innovation Management, v. 27, n. 2, p. 179, 2010.

DHALLA, R. The construction of organizational identity: key contributing external and intraorganizational factors. Corporate Reputation Review, v. 10, n. 4, p. 245-260, 2007.

ECCLES, G. Marketing, sustainable development and international tourism. International Journal of Contemporary Hospitality Management, v. 7, n. 7, p. 20, 1995.

ECHTNER, C. M.; RITCHIE, J. R. B. The meaning and measuring of destination image. The Journal of Tourism Studies, v. 14, n. 1, 2003.

;. The measurement of tourism destination image. Calgary: University of Calgary, Unpublished paper, 1991. 
FRIAS, D. M.; RODRIGUEZ, M. A.; CASTANEDA, J. A. Internet vs. travel agencies on pre-visit destination image formation: an information processing view. Tourism Management, v. 29, p. 163-179, 2008.

GALLARZA, M.; SAURA, I.; GARCIA, H. Destination image: towards a conceptual framework. Annals of Tourism Research, v. 29, n. 1, p. 56-78, 2002.

GOVERS, R.; GO, F. M.; KUMAR, K. Virtual destination image: a new measurement approach. Annals of Tourism Research, v. 34, n. 4, p. 977-997, 2007.

GRANT, A. M.; HOFMANN, D. A. Outsourcing inspiration: the performance effects of ideological messages from leaders and beneficiaries. Organizational Behavior and Human Decision Processes, v. 116, n. 2, p. 173, 2011.

HAIR JUNIOR, J. F. et al. Multivariate data analysis. 6. ed. New Jersey: Prentice Hall, 2006.

HANSS, D.; BÖHN, G. Sustainability seen from the perspective of consumers. International Journal of Consumer Studies, v. 36, n. 6, p. 678-687, nov. 2012.

HARISH, R. Brand architecture in tourism branding: the way forward for India. Journal of Indian Business Research, v. 2, n. 3, p. 153-165, 2010.

HERBERGER JUNIOR, R. A. The ecological product buying motive: a challenge for consumer education. The Journal of Consumer Affairs (pre-1986), v. 9, n. 2, p. 187, Winter 1975 .

HULLAND, J.; CHOW, Y. H.; LAM, S. Use of causal models in marketing research: a review. International Journal of Research in Marketing. v. 13, p. 181-97, 1996.

HUME, S. et al. Consumers go green. Advertising Age, v. 25, p. 3-5, set. 1989.

HUNT, J. D. Image as a factor in tourism development. Journal of Travel Research, v. 13, n. 4, p. 1-7, 1975.

HUNTER, C. Environment, development and sustainability, v. 4, n. 1, p. 7, 2002.

KAPLANIDOU, K.; VOGT, C. A structural analysis of destination travel intentions as a function of web site features. Journal of Travel Research, v. 45, n. 2, 2006.

KIM, H.; FESENMAIER, D. R. Persuasive design of destination websites: an analysis of first impression. Journal of Travel Research, v. 47, p. 3-13, ago. 2008.

KINNEAR, T. C. et al. Ecologically concerned consumers: who are they? Journal of Marketing, v. 38, n. 2, p. 20-24, abr. 1974.

KOTLER, P. et al. Marketing de lugares: como conquistar crescimento de longo prazo na América Latina e no Caribe. São Paulo: Pearson, 2006.

LACHER, R. G. Serious tourism and consumer preference for sustainable tourism certifications. 2012. Tese (Doutorado em Filosofia) - Clemson University, South Carolina (USA), 2012. 
LAGES, N. S.; VARGAS NETO, A. Mensurando a consciência ecológica do consumidor: um estudo realizado na cidade de porto alegre. In: ENCONTRO DA ASSOCIAÇÃO

NACIONAL DE PÓS-GRADUAÇÃO E PESQUISA EM ADMINISTRAÇÃ̃O

(ENANPAD), 26., 2002, Salvador (BA). Anais... Rio de Janeiro: ANPAD, 2002.

LATTIN, J.; CARROLL, D. J.; GREEN, P. E. Análise de dados multivariados. São Paulo: Cengage Learning, 2011.

LEE, G.; CAI, L. A.; O’LEARY, J. WWW.branding.states US: an analysis of brand-building elements in the US state tourism websites. Tourism Management, v. 27, n.5, p. 815-28, 2006.

LEE, J. A.; HOLDEN, S. J. S. Understanding determinants of environmentally conscious behavior. Psychology \& Marketing, v. 16, n. 5, ago. 1999.

LEE, J.-S. et al. Understanding how consumers view green hotels: how a hotel's green image can influence behavioural intentions. Journal of Sustainable Tourism, v. 18, n. 7, p. 901914, set. 2010.

MALHOTRA, N. K. Pesquisa de marketing: uma orientação aplicada. 4. ed. Porto Alegre: Bookman, 2006.

MANAKTOLA, K.; JAUHARI, V. Exploring consumer attitude and behavior towards green practices in the lodging industry in India. International Journal of Contemporary

Hospitality Management, v. 19, n. 5, p. 364-377, 2007.

MARTIN, B.; SIMINTIRAS, A. C. The impact of green product lines on the environment: does what they know affect how they feel? Marketing Intelligence \& Planning, v. 13, n. 4, p. 16, 1995.

MIHAILOVICH, P. Kinship branding: a concept of holism and evolution for the nation brand. Place Branding, v. 2, n. 3, p. 229-47, 2006.

MORRISON, A. M.; TAYLOR, J. S.; DOUGLAS, A. Website evaluation in tourism and hospitality: the art is not yet stated. Journal of Travel \&Tourism Marketing, v. 17, n. 2/3, p. 233-251, 2004.

NYSVEEN, H.; METHLIE, L.; PEDERSEN, P. E. Tourism web sites and value-added services: the gap between customer preferences and web sites offerings. Information Technology \& Tourism, v. 5, p. 165-174, 2003.

OKADA, E. M.; MAIS, E. L. Framing the "green" alternative for environmentally conscious consumers. Sustainability Accounting, Management and Policy Journal, v. 1, n. 2, p. 222234, 2010.

O'SHAUGHNESSY; J.; O'SHAUGHNESSY, N. J. Treating the nation as a brand: some neglected issues. Journal of Macromarketing, v. 20, n. 1, 2000.

OTTMAN, J. A green marketing: challenges and opportunities for the new marketing age. New York: NTC Business Books, 1994. 
PEREIRA, S. J. N.; AYROSA, E. A. T. Atitudes relativas a marcas e argumentos ecológicos: um estudo experimental. Revista Eletrônica de Gestão Organizacional - Gestão.Org, v. 2, n. 2, maio/ago., 2004.

PIMENTEL, E.; PINHO, T.; VIEIRA, A. Imagem da marca de um destino turístico. Turismo - Visão e Ação, v. 8, n. 2, maio/ago., p. 283-298, 2006.

PINTO, R. A formação das imagens no turismo: itinerário teórico e proposta de um modelo operacional. Revista Turismo em Análise, v. 23, n. 3, p. 552-574, dez. 2012.

ROCHA, A. L. P. Revealing the brazilian green consumer profile: a study on rio de janeiro citizens and its contributions to marketing strategists. In: GBATA INTERNATIONAL CONFERENCE, 9., 2007, Taipei (Taiwan). Anais... Taipei: PUC-RJ, 2007.

Intenções e ações em relação a escolhas de produtos ecológicos: estudos sobre o comportamento do consumidor carioca. Revista Contemporânea de Economia e Gestão, v. 9, n. 1, jan./jun. 2011.

ROCHA, A. L. P. da; SANTOS, T. P. C. dos. Desvendando o perfil do consumidor verde: um estudo longitudinal na cidade do Rio de Janeiro. In: ENCONTRO NACIONAL SOBRE GESTÃO EMPRESARIAL E MEIO AMBIENTE (ENGEMA), 9., 2007, Curitiba (PR). Anais... Curitiba: , 2007. In: Anais... Curitiba: EAESP, 2007.

ROBERTS, J. A. Green consumers in the 1990s: profile and implications for advertising. Journal of Business Research, v. 36, n. 3, p. 217-231, 1996.

ROBERTS, J. A.; BACON, D. R. Exploring the subtle relationships between environmental concern and ecologically consumer behavior. Journal of Business Research, v. 40, n. 1, p. 79-89, 1997.

ROBINOT, E; GIANNELLONI, J.-L. Do hotels' "green" attributes contribute to customer satisfaction? The Journal of Services Marketing, v. 24, n. 2, p. 157-169, 2010.

SAMDAHL, D. M.; ROBERTSON, R. Social determinant of environmental concern: specification and test of the model. Environment and Behavior, v. 21, n. 1, p. 5-81, 1989.

SAMPIERI, R. H.; COLLADO, C. F.; LUCIO, P. B. Metodologia de pesquisa. 3. ed. São Paulo: McGraw-Hill, 2006.

SCHLEGELMILCH, B. B.; BOHLEN, G. M.; DIAMANTOPOULOS, A. The link between green purchasing decisions and measures of environmental consciousness. European Journal of Marketing, v. 30, n. 5, p. 35-55, 1996.

SERPA, D. A.; AVILA, M. G. Efeito framing e influência da experiência gerencial em marketing em decisões de compra: um teste experimental. In: ENCONTRO DA ASSOCIAÇÃO NACIONAL DE PÓS-GRADUAÇÃO E PESQUISA EM ADMINISTRAÇÃO (ENANPAD), 24., 2000, Florianópolis (SC). Anais... Florianópolis: ANPAD, 2000.

STRAUGHAN, R. D.; ROBERTS, J. A. Environmental segmentation alternatives: a look at green consumer behavior in the new millennium. Journal of Consumer Marketing, v. 16, n. 6, p. 558-575, 1999. 
TAMOTO, R. Holandeses vêm trazer tecnologia e inovação ao Brasil. Diário do Comércio, nov. 2012. Disponível em: <http://www.dcomercio.com.br/index.php/economia/sub-menunegocios/99899-holandeses-vem-trazer-tecnologia-e-inovacao-ao-brasil>. Acesso em: 13 fev. 2013.

TUCKER JUNIOR, L. R. Identifying the environmentally responsible consumer: the role of internal external control of reinforcements. The Journal of Consumer Affairs (pre-1986), v. 14, n. 2, p. 326, Winter 1980.

WILLIAMS, P.; PALMER, A. Tourism destination brands and electronic commerce: towards synergy? Journal of Vacation Marketing, v. 5, n. 3, p. 263-275, 1999.

WTO. World Tourism Organization. Sustainable tourism development: guide for local planners. Madrid: Ed. WTO, 1993.

Handbook on tourism product development. Madrid: Ed. WTO, 2011.

VELTER, A. N. et al. Atitudes dos consumidores a partir da teoria das pistas e consciência ambiental: contribuições ao estudo do Green Marketing. Revista de Administração UFSM, Santa Maria, v. 2, n. 3, p. 399-416, set./dez. 2009.

VOGT, C. A.; FESENMAIER, D. R. Expanding the functional information search model. Annals of Tourism Research, v. 25, n. 3, p. 551-578, 1998.

ZIMMER, M. R. et al. Green issues: dimensions of environmental concern. Journal of Business Research, v. 30, n. 1, p. 63-74, 1994. 